DOI 10.31489/2020Ped1/48-54

IRSTI 77.29.11 (UDC) 796/799.378

\author{
Yer.K. Seisenbekov ${ }^{1}$, Y. Mutafova-Zaberska ${ }^{2}$, U.S. Marchibaeva ${ }^{3}$, A.A. Bekov ${ }^{4}$, B.B. Amal ${ }^{4}$ \\ ${ }^{1}$ Abay Kazakh National Pedagogical University, Almaty, Kazakhstan; \\ ${ }^{2}$ Vasil Levski National Sports Academy, Sofia, Bulgaria; \\ ${ }^{3}$ L.N. Gumilyov Eurasian National University, Nur-Sultan, Kazakhstan; \\ ${ }^{4}$ Regional Social and Innovation University, Shymkent, Kazakhstan \\ (E-mail Yerlan_fks@mail.ru)
}

\title{
Functions of sport that increase its social significance
}

\begin{abstract}
The article highlights information on the functions of sports in accordance with the broad sports movement, which are strengthened as a factor in the socialization of individuals, social integration, and international relations. Research objectives: due to the process of sports activities arise various interpersonal relationships, which are manifested in action: interpersonal, intergroup, intercollective and broader, which may have signs of solidarity, community, rivalry, competition. The scientific and practical significance of the work consist the fact that sports relations (interpersonal rivalry relations or between the community of individual athletes, between athletes and coaches) are somehow included in the system of social relations that go out beyond the sport. The totality of all these relations underlies the formative influence of sport on the individual, its assimilation of social experience in the realm of sports and, as a consequence, more general social experience. Sport is considered one of the serious means of human communication, developing the individual's social experience - the experience of inter-human communication and socially justified behavior. The result of the above relations that have developed in the practice of sports communication between a coach and a ward are outstanding achievements of famous athletes in major competitions like the Olympic Games, world, continental or country championships. In the education system, particularly in school sports, especially, through the system of social relations established a comprehensive relationship between the coach and the ward, which is the beginning of a professional attitude to sports.
\end{abstract}

Keywords: methods, functions, specificity and importance of sports, education system in sports.

\section{Introduction}

To increase the social significance of sports, recommended tools and methods that contribute to solving these problems of society, impacts that contribute to the upbringing of a new person and finally, impacts as solving specific sports problems. One of its characteristics of social impact on the personality of an athlete is the function of sports. Under the functions of sports understand the objectively inherent properties of it to influence a person and human relations, to satisfy and develop certain needs of the individual and society. Functions of sports can also be conditionally divided into specific (specific only to it as a special phenomenon of reality) and general. The first is a competitive reference and heuristic function of achievement. The second place is occupied by functions having social and social significance. Such - as a function of personality-oriented education; Training and development; recreational function; emotional and spectacular function; functions of social integration and socialization of the individual; communicative function and economic function [1].

\section{Theoretical and practical significance of the work}

The basis of the specifics of the sport and its function is that it arose, developed as a competitive activity, which is specially adapted to maximize the identification, unified comparison and objective assessment of certain human capabilities in the form of competition oriented to victory or, perhaps, the highest achievement in this very competitive activity. This implies, first of all, the importance of sports as a kind of standard for assessing a person's abilities, that is, a specific sports control functions of the sport [2].

Detected and recorded achievements in sports (in the form of quantitatively estimated records, fulfilled classification standards), gaining widespread recognition, serve as original gauges of individual and universal human opportunities realized in sports, and at the same time, clear, precise guidelines on how to realize these opportunities. Unlike other measurement standards, the «sports standard» of human capabilities historically does not remain unchanged, but progresses, thereby stimulating the athlete's mobilization of selfimprovement efforts aimed at influencing the development of his abilities. Such functions are most pronounced, naturally, in the sport of the highest achievements, where sports achievements of a universal 
scale are established and enhanced. But on the one or another hand they are characteristic of sports in general. They are inseparable from the essence of it as activities aimed at self-determination and selfassertion of an individual through humanely debugged forms of honest rivalry [3].

\section{The purpose and object of research}

In relation to sport, the concept of «function» means the objectively inherent properties of it to influence society and the individual. The nature of its impact is quite multifaceted and diverse. In this regard, in the sociology of sports, proposed a classification of the functions of sports which provides for the separation of social, general pedagogical and specifically pedagogical functions of sports depending on the level of their manifestation [4].

\section{Relevance}

The group of social functions of sport is designed to reflect the objective properties inherent in sport, to influence the solution of the general social problems of the state, general pedagogical - the problems of the system of education of a new person and especially pedagogical - problems of physical improvement of a person.

An analysis of the scientific and methodological literature and publications of the authors in a similar direction shows that the essence of the specific functions of sports characterize it, first of all, as a special type of activity that reveals human opportunities in specially created conditions and is steadily pushing the frontier of their apparent boundaries. This largely determines both the personal and social value of sports, its contribution to the culture of society, and its wider use for socially significant purposes. Besides, in addition to the above, according to the work of Russian colleagues in the research and partial solution of the optimal legal protection regime for sports training methods and ways as the results of creative activity. The patenting process for a training methodology involves one serious difficulty. The current legislation allows the patenting of the method, but the method means the impact of a material object on a material object. Revealed that patenting of methods and techniques of sports training complies with the law and is generally advisable; conditions for patenting training methods are identified. The mentioned features do not indicate that sports training methods cannot be protected by means of intellectual property law. These features only show that the question of the possibility of protecting the intellectual property law of training methods require research [5]. The social meaning of sport is reflected in 6 functions (Figure 1). These are: preparatory-labor, preparatory-defensive, reference, heuristic (search), cultural-spectacular and prestigious sports functions.

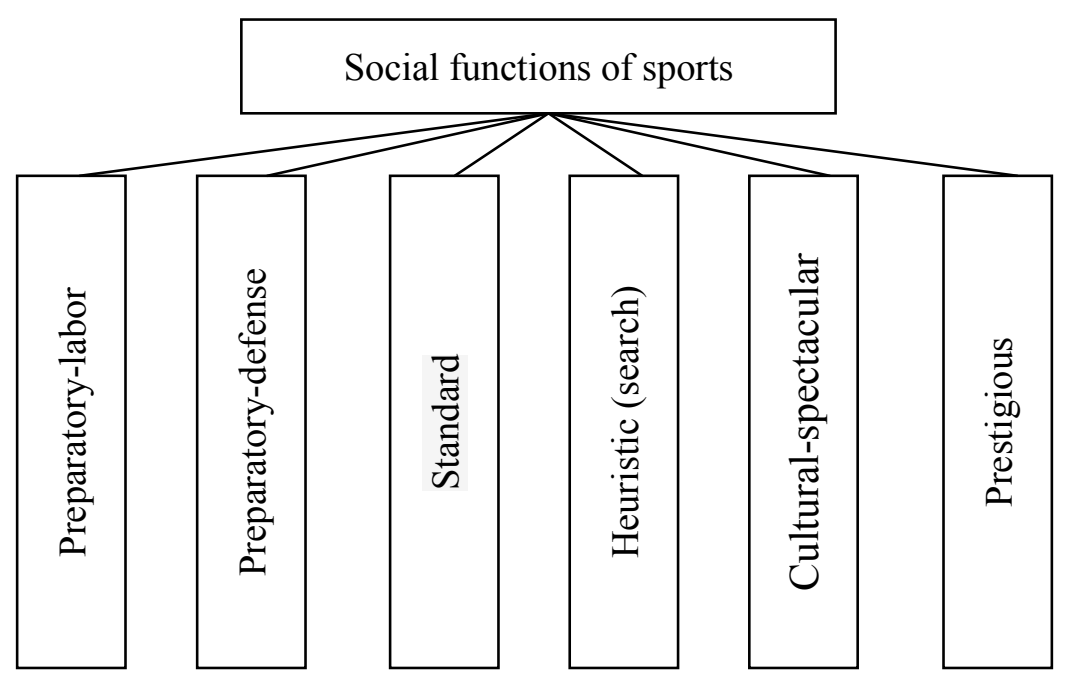

Figure 1. Social functions of sports

\section{Methodology}

In the process of starting sports, not only previously achieved results are reproduced, but also the possibilities of new achievements are realized, and increasingly effective factors for improving sports are sought and embodied in outstanding results. This heuristic function of achievement is in one way or another characteristic of sport in general, but it is most fully expressed in the field of sports of the highest achievements. 
Indeed, on the way to them, one who claims to have a truly outstanding result must find new means, methods and conditions for the full mobilization and increase of the body's functional capabilities derived from nature, learn to use them most effectively to rise to the level of sports performance previously not achieved by anyone. The means and methods of a person transforming his natural qualities become a common cultural heritage when he penetrates into mass practice. It is also important that the cognitive data obtained on the way to sports achievements acquire quite serious scientific significance [6].

The preparatory labor functions of sports. Labor provides the basis for the life of any society. They are characterized by the level of power of the country. The indicated function in sporting activities is realized through the skillful development of all personality traits and qualities necessary for fruitful activity in all spheres and spheres of a person's life (economics, production, etc.).

The reference function of sport is closely related to its function of heuristic achievement, which is important both for the individual and for society. The social value of sports lies in the fact that this is a special type of heuristic activity, that is, creative search activity, including moments of opening, opening of a new one. Unlike other types of heuristic activity, sport is not focused on discovering something that is beyond the limits of the individual, but on the practical identification of our own achievable abilities, as well as on effective tools and methods for their implementation at an ever higher level, and these based on the abilities of the athlete himself. The social, first of all, includes the functions of personality-oriented education, training and development. Sport presents great opportunities not only for physical and sports improvement, but also for moral, aesthetic, intellectual and labor education. The attractive power of sports, high requirements for the manifestation of physical mental forces represent wide opportunities for personality-oriented education of spiritual traits and qualities of a person. It is significant, however, that the final result in achieving educational goals depends not only and not so much on the sport itself, but on the social orientation of the entire system of education and development. Thus, the educational opportunities of sports are not realized on their own, but through a system of educationally-oriented relations that take shape in the field of sports [7].

Recreational function is manifested in the positive impact of sports on the condition and functional capabilities of the human body. This is especially pronounced in children and youth sports, where the beneficial effects of sports on a developing and emerging organism are invaluable. Definitely at this age the foundations of health are laid, the skills of systematic physical exercises are inculcated and personal and public hygiene habits are formed. Sport is at the same time a source of positive emotions, it levels the mental state of children, allows you to relieve mental fatigue, and makes it possible to know «muscle joy». Especially great is its role in eliminating the negative phenomena of physical inactivity in children [8].

Mostly, sports are interesting as an exciting sight. The emotional and spectacular function of sports is associated with its main specific properties as a competitive activity, due to its aesthetic appeal and increases as the audience of its fans grows. Without fans, sports would not have become a universally significant social phenomenon. The audience of sports shows has expanded unusually in our time, which was facilitated by the progress of technical media, especially television. At the same time, the influence of sports on the emotional world of people has increased [9].

The attractiveness and effectiveness of sports in this regard is based on the objectively inherent aesthetic properties. The life-affirming beginning of sporting activity, reflected in its main features, demonstration in competitions of the highest and harmonious manifestations of the physical and spiritual qualities of a person, the true beauty of an honest, courageous and uncompromising struggle for victory, the perfection of forms of movements and much more in sport meet, in principle, the most stringent aesthetic criteria [10].

The impact of sports on spectators is not unambiguous, not always exalting. The nature of such an impact depends both on the purity of the sports competition itself, especially on the fact that sports and ethical norms and rules are somewhat firmly observed, as on the culture and upbringing of the fans. Under certain circumstances, not only positive, but also negative effects are possible, which can be expressed in the dangerous unleashing of primitive emotions. Thus, the influence of sport on the minds of its fans can be contradictory. Spectacular interest in sports should not be the only one [11].

While characterizing the social role of sport, it is important to keep in mind its considerable economic importance. The material investments of society in the development of sports are repeatedly paid off, first of all, by increasing the general level of working capacity, strengthening health, and increasing the duration of the highly active life of a working person - the most valuable «capital» of society. Economic relations can become dominant in some part of the sport when it is professionalized and becomes, in fact, a business sector subject to commercial interests. This is a professional-commercial sport, long cultivated in America's and EMEA. According to developing the law of business, its acquired features that do not stem from the essence 
of purely sports relations, including those that rightly cause negative assessments (when sports and competitive principles and norms of sports ethics are sacrificed to commercial interests or, especially, when the latter lead to financial and other fraud, etc.). However, commercialization is not an inevitable property of professional sports in general. The material investments of society on the development of sports are «paid off»" by increasing labor productivity, improving the health of workers, and the creative longevity of man. Also important are the revenues derived from the commercialization of sports, the operation of sports facilities and the development of the sports industry. Physical education and sports, their implementation in the process of scientific organization of labor, can significantly increase labor productivity. According to some experts, such an increase can be up to $12 \%$ and significantly improve the final results of productive labor [12].

Financial importances are also having financial resources received from sports spectacles, the operation of sports facilities. However, this is a small fraction of what the state and public organizations invest in the development of sports. The main value of our society is health. And in this aspect, the role of sport is invaluable. The class limitations on the functioning and development of physical culture in any exploiting society are determined not only by the subjective interests of the ruling classes, but also by objective economic relations.

The considered opportunities to use sports for various purposes were a prerequisite for the differentiation of sports movement in heterogeneous directions. In turn, this contributed to a more complete functioning of sports in society, its importance as a whole as a means of satisfying various social needs increased.

In the modern world sports movement, clearly highlights two typical directions and the corresponding sections of sports practice, which are often referred to as «mass sports» and «big sports», quite accurately they can be called public sports and sports of the highest achievements have been quite clearly distinguished.

Public, ordinary sport (mass) - is called mass, because a large number of people involved in it are practically involved in sports activities. In another case, sport can be described as ordinary, but not mass. Within the framework of this type of sports movement, an ordinary (ordinary) level of sports results is achieved, which, in principle, is generally accessible and less high than the level of absolute sports achievements. The corresponding section of the sports movement is basic in relation to the sport of the highest achievements, since the latter develops on the basis of the development of the former, although the relationship between them is not direct, but mediated by a number of conditions and therefore manifests itself mainly in the general trend.

The main differences in mass, or ordinary, sport is determined by the fact that ordinary sports activity is built up depending on other activities that dominate life (academic, labor), and therefore occupies a subordinate place in an individual lifestyle; the time and effort spent on sports here is rather strictly limited, which objectively limits the level of achievements. This does not mean that the athlete's personal attitudes in such a situation do not include the desire to achieve high results. Such an aspiration is stimulated by the essence and the internal organization of sports in general, but the objective conditions for the implementation of sports claims in the framework of ordinary sports introduce their limitations. Outstanding achievements in modern sports are becoming real with the daily large expenditures of time and energy for sports activities over the years.

Depending on the social sphere in which mass sport is being cultivated, the system of sports activities is modified in one way or another. Among these modifications, the following are most common:

- «school sports» - the practice of using sports in the school system of general education, upbringing of the younger generation, where sports are subordinated, first of all, to general pedagogical principles and are built in accordance with the unified logic and conditions for organizing a multi-component educational process.

- «professional and applied sports» - the practice of using sports in applied training for selected professional activities (production, military service, etc.);

- «physical culture-conditioned sport» of mature contingents of the population who are not dominated by purely sporting attitudes and sports are built mainly according to the type of physical education and sports training, which helps to maintain the previously acquired «condition», with strictly regulated participation in competitions;

- «recreational sports» - the practice of using the elements of sports as a means and method of achieving the effect of a healthy rest - entertainment, active restoration of operational performance and organization of interesting, emotionally rich leisure. 
There is a differentiation in sports of the highest achievements.

Sports of the highest achievements - unlike ordinary sports, is focused on absolute sports results and a steady increase in their level. The implementation of this installation in our time is possible only under the condition of everyday long-term expenditure of time and effort on sports activities and subject to the extraordinary athletic giftedness of the individual.

Achievement in big sport is possible only due to constant training and competitive activity with great physical and mental stress. Performance in competitions imposes a great responsibility on the athlete; the high price of each error, each unsuccessful start becomes a factor determining the stringent requirements for his psyche. This is the specificity of sports of the highest achievements. Sports activity in the field of sports of the highest achievements turns into the main one, occupying a dominant position in the individual lifestyle of an athlete for many years. But this is not for everyone, only for those who really have outstanding sports abilities. So, in countries developed in sports terms, the proportion of athletes actually reaching the international level is only one hundredths of a percent or less of the total number of people involved in sports in the country.

In the modern period of its development, the sport of the highest achievements is becoming increasingly professionalized. This means that for a certain part of athletes starting with the so-called amateur sports, sports activity under certain conditions takes the main place in the lifestyle. Without such professionalization, the world's heights of modern sports would be insurmountable.

In reality, modern professional sports are not at all homogeneous. It distinguishes between professional and commercial sports that have emerged as a branch of business, and professionalized sports of truly highest achievements, which are called professional-super-achievement sports, that are not limited to business. Professional and commercial sport, which has developed as a kind of business sector, lives not only according to the laws of the sport itself, but according to the laws of obtaining financial profit, commerce, profitable entrepreneurship based on the material of a sports spectacle.

«Professional-achievement» sport is its most important feature - the constant assault on the true heights in sports.

Super achievement sport grows on the basis of mass sports practice and develops depending on its condition; in turn, the progress of high-performance sports affects the state of ordinary sports and can be a powerful catalyst for its development. The sport of the highest achievements plays a leading role in relation to the rest of the practice of sport. Sport of the highest achievement is oriented directly to the absolute parameters of sports results, including achievements of international, universal scale. The value of sport is used as a means of improving physical development, strengthening health, increasing creative longevity, and education. Going in for sports is one of the means for a person to satisfy his need for movements in his playing form.

\section{Results}

The increased level of the body's functional capabilities and achieving during the process as a result of playing sports and the foundation of useful skills and abilities created at the same time can significantly predetermine the athlete's accelerated development of professional labor, military and other socially necessary activities and contribute to improvement in it. In the educational system, including self-education, sport has large importance and as one of the means of directly applied preparation for labor and combat activities. In this regard, especially valuable sports are simulating the essential features of the chosen professional activity, as known as professionally applied sports.

A large role is given to sports and working with the adult population. It is a mean of healing, protection from the adverse effects of scientific and technological progress with its characteristic sharp decrease in physical activity at workplace and home. Sport is one of the most popular forms of organizing healthy leisure, recreation and entertainment. This is especially evident in mass sports, where the goals are not set to achieve high sports results. The basis of this kind of interest in sports is not only its external attractiveness. Empathizing with those who act in the sports arena, the fans seem to identify themselves with the athlete, as if they are participating in sports achievements, wrestling and resolving sports conflicts at an emotionallyfigurative level in an atmosphere of lively communication, both with their supporters and with the opposite configured. At the same time, there are often striking role models and reasons to establish oneself in one's life ideas. 


\title{
Conclusions
}

In the line with the broad sports movement, the value of sports as a factor in the socialization of the individual, social integration and international relations is growing. In the process of sports activity and in connection with it, various interhuman relations arise and are manifested in action: interpersonal, intergroup, intercollective and broader, which may have features of solidarity, community, rivalry, competition. Specific sports relations (interpersonal relations of rivalry and the commonwealth of individual athletes, between athletes and coaches, etc.) are somehow included in the system of social relations that go beyond sports. The totality of all these relations forms the basis of the shaping influence of sport on the individual, the assimilation by itself of social experience in the field of sport, and through it more general social experience. Sport is therefore considered one of the serious means of socializing a person. It means that the individual's development of social experience - the experience of interpersonal communication and socially justified behavior.

\section{References}

1 Выдрин В.М. О ценностном аспекте физического воспитания / В.М. Выдрин, Ю.М. Николаев // Теория и практика физического воспитания. - № 5. - М., 1979. - С. 13-15.

2 Лубышева Л.И. Концепция формирования физической культуры человека / Л.И. Лубышева. — М.: ГЦОЛИФК, 1992. - C. 78-91.

3 Dill D. The economy of muscular exer cise / D. Dill // Physiology. Rev. - 1984. - Vol. 16. — P. 263.

4 Olympic School Project. — Melbourne, 1989. — P. 44.

5 Титова Е.В.Способ и методика спортивной тренировки как объект интеллектуальных прав / Е.В. Титова, Е.А. Останина // Человек. Спорт. Медицина. - 2018. - T. 18, № 3. — С. 69-76. DOI: 10.14529/hsm180307

6 Сластенин В.А. Введение в педагогическую аксиологию: учеб.-позиция для студентов вузов / В.А. Сластенин, Г.И. Чижакова. - М.: Академия, 2003. - С. 192.

7 McClelland D.C. The Achievement Motivation / D.C. McClelland, J.W. Atkinson. - New York, 1953. — P. 11-27.

8 Мамытов А. Теория спорта / А. Мамытов. - Каракол, 2005. - С. 236.

9 Федоров А.И. Психосоциальные, поведенческие и стрессовые факторы здоровья современных подростков /А.И. Федоров, В.Н. Авсиевич, Е.К. Сейсенбеков // Олимпийский спорт, физкультура, здоровье нации в современных условиях: материалы XVI Междунар. науч. конф. - Луганск, 2019. - С. 442-450.

10 Столяров В.И. Ценности спорта и пути его гуманизации / В.И. Столяров. - М.: РГАФК, 1995. — С. 254.

11 Собянин Ф.И. Профессиональная подготовка учителей физкультуры на основе культурологического подхода: дис. ... д-ра пед. наук: 13.00.04 - «Теория и методика физического воспитания, спортивной тренировки, оздоровительной и адаптивной физической культуры» / Ф.И. Собянин. — СПб., 2001. — 291 с.

12 Мусарова А.Б. Спорт как социально-педагогический феномен на практике и тренер по спорту (например, водное поло) / А.Б. Мусарова. - Астана, 2011. - С. 11-59.

\section{Е.К. Сейсенбеков, Ю. Мутафова-Заберска, Ұ.С. Маршыбаева, А.А. Беков, Б.Б. Амал}

\section{Спорттың әлеуметтік маңызын көтеретін іс-қызметтер}

\begin{abstract}
Мақалада кең спорттық қозғалысқа сәйкес жеке тұлғаларды әлеуметтендіру, әлеуметтік интеграция және халықаралық қатынастардағы спорт функциялары туралы ақпарат берілген. Спорттық іс-әрекет процесінде әр түрлі адами қатынастар пайда болады, олар мына іс-әрекетте көрінеді: тұлғааралық, топаралық, ұжымаралық және кең ауқымда; ал оларда ынтымақтастық, қауымдастық, бақталастық, бәсекелестік белгілері болуы мүмкін. Жұмыстың ғылыми және практикалық маңыздылығы спорттық қатынастардың (спортшылар мен жаттықтырушылар арасындағы, жекелеген спортшылар қауымдастығы және тұлғааралық бәсекелестік қатынасы) спорт аясынан шығып кеткен әлеуметтік қатынастар жүйесіне енетіндігінде. Бұл қатынастардың жиынтығы спорттың жеке адамға қалыптасу әсерінің, оның спорт саласындағы әлеуметтік тәжірибесінің игеруін және жалпы әлеуметтік тәжірибенің негізінде жатыр. Спорт адамның әлеуметтік тәжірибесін - адами қарым-қатынас тәжірибесін және әлеуметтік негізделген мінез-құлықты дамыта отырып, адаммен қарым-қатынастың маңызды құралдарының бірі болып саналады. Бапкер мен тәлімгерлерінің арасындағы спорттық қарым-қатынастың тәжірибесінде қалыптасқан, жоғарыда аталған қатынастардың тәжірибесі атақты спортшылардың олимпиада ойындары, құрлық, ел, әлем чемпионаттары сияқты ірі жарыстардағы жетістіктері болып табылады. Білім беру жүйесінде, атап айтқанда мектеп спортында, әлеуметтік
\end{abstract}


қатынастар жүйесі арқылы жаттықтырушы мен оның тәлімгерлері арасында жан-жақты байланыс қалыптасады, бұл спортқа деген кәсіби көзқарастың бастауы болып табылады.

Кілт сөздер: спорттың амалдары, әдістері, қызметтері, арнайылығы және маңызы, спорттағы тәрбие жүйесі.

\title{
Е.К. Сейсенбеков, Ю. Мутафова-Заберска, У.С. Марчибаева, А.А. Беков, Б.Б. Амал \\ Функции спорта, повышающие его социальную значимость
}

\begin{abstract}
В статье освещена информация о функциях спорта, которые, в соответствии с широким спортивным движением, усиливаются как фактор социализации личности, социальной интеграции и международных отношений. В процессе спортивной деятельности возникают различные межчеловеческие отношения, которые проявляются в действии: межличностные, межгрупповые, межколлективные и более широкие, которые могут иметь признаки солидарности, общности, соперничества, конкуренции. Научная и практическая значимость работы заключается в том, что спортивные отношения (межличностные отношения соперничества и сообщества отдельных спортсменов, между спортсменами и тренерами), так или иначе, включены в систему социальных отношений, выходящих за рамки спорта. Совокупность этих отношений лежит в основе формирующего влияния спорта на личность, усвоения ею социального опыта в области спорта и, как следствие, более общего социального опыта. Спорт считается одним из серьезных средств общения человека, развивающим у индивида социальный опыт опыт межчеловеческого общения и социально оправданного поведения. Результатом названных выше отношений, сложившихся в практике спортивного общения между тренером и подопечным, являются выдающиеся достижения известных спортсменов в крупных состязаниях, таких как олимпийские игры, чемпионаты мира, континента, страны. В системе образования, в частности, в школьном спорте, именно через систему социальных отношений устанавливается всесторонняя связь между тренером и подопечным, которая является началом профессионального отношения к спорту.
\end{abstract}

Ключевые слова: средства, методы, функции, специфика и значение спорта, система образования в спорте.

\section{References}

1 Vydrin, V.M., \& Nikolayev, Yu.M. (1979). O tsennostnom aspekte fizicheskoho vospitaniia [On the value aspect of physical education]. Teoriia i praktika fizicheskoho vospitaniia - Theory and practice of physical education, 4, 13-15. Moscow [in Russian].

2 Lubysheva, L.I. (1992). Kontseptsiia formirovaniia fizicheskoi kultury cheloveka [The concept of the formation of physical culture of man]. Moscow: GTSOLIFK [in Russian].

3 Dill, D. (1984). The economy of muscular exer cise. Phisiol. Rev., Vol. 16, 263.

4 Olympic School Project. (1989). Melbourne.

5 Titova, E.V., \& Ostanina, E.A. (2018). Sports Training as the Object of Intellectual Property Rights, Human. Sport. Medicine, Vol. 18, No. 3, 69-76. DOI: 10.14529/hsm180307 [in Russian].

6 Slastenin, V.A., \& Chizhakova, G.I. (2003). Vvedeniye v pedahohicheskuiu aksiolohiiu [Introduction to Pedagogical Axiology]. Moscow [in Russian].

7 McClelland, D.C., \& Atkinson, J.W. (1953). The Achievement Motivation. New York.

8 Mamytov, A. (2005). Teoriia sporta [Theory of sport]. Karakol [in Russian].

9 Fedorov, A.I., Avsiyevich, V.N., \& Seisenbekov, Yer.K. (2019). Psikhosotsialnyye, povedencheskie i stressovye faktory zdorovia sovremennykh podrostkov [Psychosocial, behavioral and stressful health factors of modern adolescents]. Proceedings from Olympic sport, physical education, health of the nation in modern conditions: XVI Mezhdunarodnaia nauchnaia konferentsiia - XVI International scientific conference. (pp. 442-450). Lugansk [in Russian].

10 Stolyarov, V.I. (1995). Tsennosti sporta i puti eho humanizatsii [The values of sport and the ways of its humanization]. Proceedings from. Moscow: RHAFK [in Russian].

11 Sobyanin, F.I. (2001). Professionalnaia podhotovka uchitelei fizkultury na osnove kulturolohicheskoho podkhoda [Vocational training of physical education teachers on the basis of a culturological approach]. Extended abstract of doctors thesis. SaintPetersburg [in Russian].

12 Musarova, A.B. (2011). Sport kak sotsialno-pedahohicheski fenomen na praktike i trener po sportu (na primere vodnoo polo) [Sport as a socio-pedagogical phenomenon in practice and a sports trainer (for example, water polo)]. Astana [in Russian]. 